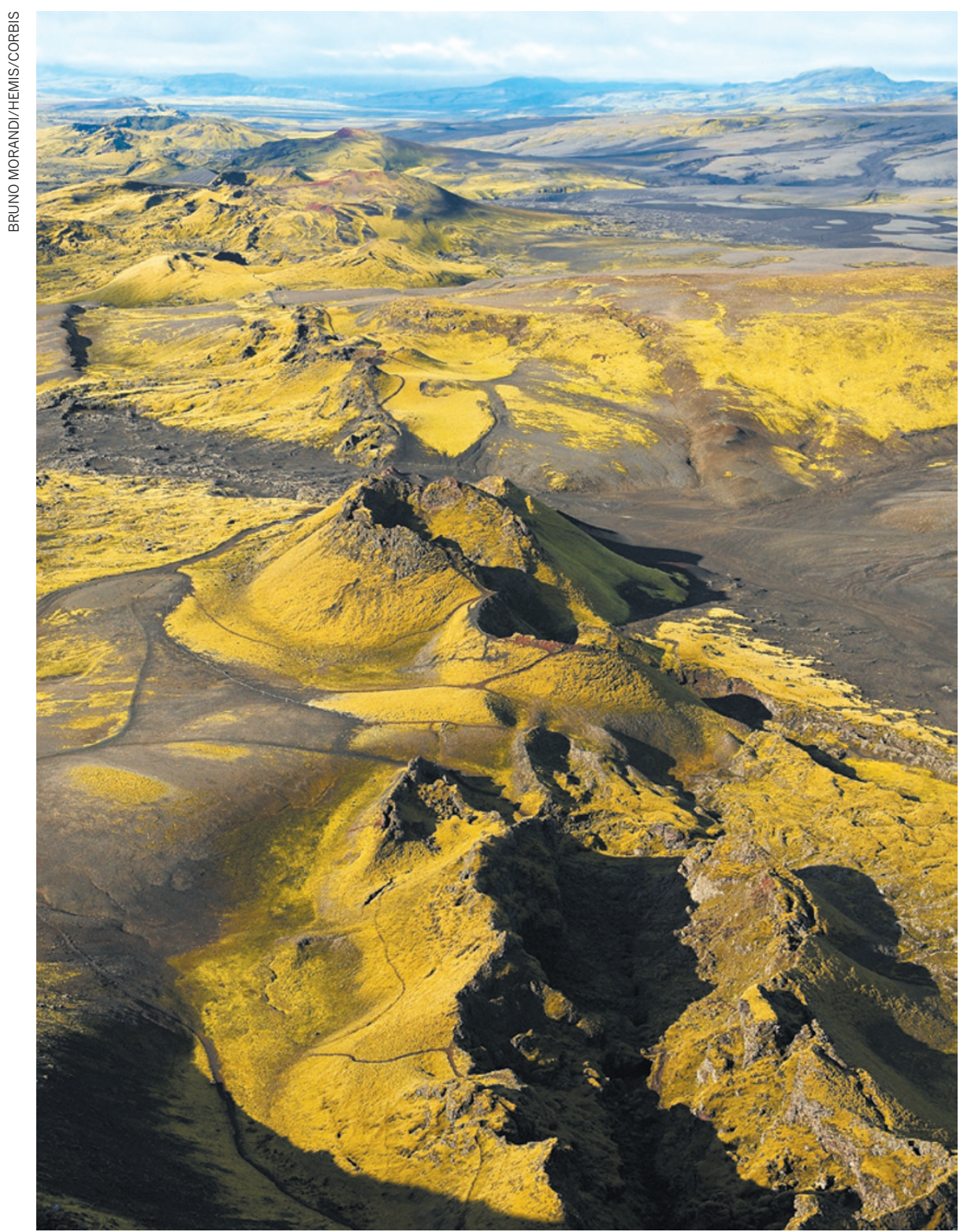

Cinder cones in Skaftafell National Park, Iceland, mark the site of the 1783 Laki eruption.

\title{
GEOLOGY
}

\section{Parsing eruptions}

\section{Ted Nield weighs up histories of two momentous volcanic events in Iceland and Indonesia.}

\section{$\mathrm{T}$} wo chronicles of two volcanic eruptions -32 years and thousands of kilometres apart - are emerging within months of each other. In Island on Fire, Alexandra Witze and Jeff Kanipe examine the late-eighteenth-century Lakagígar eruption (usually known as Laki) in Iceland. Gillen D’Arcy Wood gives us Tambora, a history of an 1815 colossal super-eruption in Indonesia that had a worldwide impact. Both left indelible marks in the historical and cultural, as well as geological, records.

Laki blew in 1783, when a section of southwestern Iceland split open and huge volumes of gassy lava and ash spewed out. The remains of the wall of fire can still be seen, striding across the landscape as a line of moss-covered cinder cones. The eruption lasted for eight months, and its global death toll is estimated in the millions. Crops failed
Island on Fire: The Extraordinary

Story of Laki: The Volcano That Turned Eighteenth-Century Europe Dark

ALEXANDRA WITZE AND JEFF KANIPE

Profile Books: 2014

Tambora: The Eruption That Changed the World

GILLEN D'ARCY WOOD

Princeton University Press: 2014

across northern Europe, possibly hastening the onset of the French Revolution. Laki's distal effects were documented by Benjamin Franklin, then US ambassador in Paris, and British naturalist-priest Gilbert White, although neither knew for sure where the dry, sulphurous fogs came from. Similar eruptions are bound to recur, and in Island on Fire Witze and Kanipe pose two questions. What happened then? And how would we cope with such an event today, given the air-traffic chaos caused by the 2010 eruption of that relative pipsqueak Eyjafjallajökull?

In describing Laki, Witze and Kanipe apply modern volcanological insight to a classic eyewitness account by Reverend Jón Steingrímsson (available in English as Fires of the Earth; Nordic Volcanological Institute, 1998). A scamper through plate tectonics and mantle-plume theory puts Iceland in context, before a survey of the world's 'supervolcanoes'. Subsequent chapters describe Laki's local and global effects, and revisit the site as it is now. A general tutorial on volcanic hazards precedes a final section on how modern society might fare, and when we can next expect to have to rise to that challenge. I need hardly shout 'spoiler alert' before I give away the unsurprising answers of 'not well', and 'possibly soon'.

The descriptions of modern interpretations of the eruption are lively and confident, and the book provides an excellent background that also broadens out to consider global volcanic hazards generally. But its didactic structure and approach can disappoint, coming as it does from two science writers (one of whom, Witze, works for Nature). The text resembles admirable lecture notes - touching on everything, with references to where one might find the more interesting details.

Despite this academicism, which many will welcome, the story is sometimes oversold. Europe was shrouded in dry fogs and suffered widespread acid rain, but it was never "turned dark" by Laki. Some geology is oversimplified and thereby rendered less interesting than it should be. Earth's magnetic field is not created by molten nickel and iron merely sloshing about in Earth's core, for example. The physics of the liquid dynamo are more controversial than Witze and Kanipe imply. Also given short shrift is Steingrímsson. The story of Laki hardly lacks harrowing tales of death by starvation, asphyxia or fluorine poisoning, much of it described by the cleric. Steingrímsson has long been revered - in life 
as a miracle-worker for seeming to stop the lava through the power of prayer when he celebrated a 'fire mass' that luckily coincided with the flow's final halt, and today as the meticulous chronicler of the eruption. His amazing career is here reduced to a litany of unfortunate events.

Tambora's stupendous 1815 eruption, by contrast, can hardly be oversold. Wood broadens our understanding beyond the 'year without a summer' cliché and the oft-parroted story of Mary Shelley and Lord Byron gloomily penning Frankenstein and Darkness in the eruption's aftermath while staying at the Villa Diodati near Lake Geneva, history's most famous holiday let. Tambora's eruption devastated the island of Sumbawa in Indonesia, and led to a decade of adverse weather that spread starvation and disease across North America, Europe, India and China - notably Yunnan Province, where successive crop failures turned a rice bowl into an opium-growing state.

Wood's command of the scientific literature is impressive, and more than matched by his knowledge of world history during this horrific episode of catastrophic global climate change. With the mass of information he has assimilated, he skilfully weaves a tale full of human and cultural interest, drawing in a "forgotten" 1816-18 Irish potato famine and Monticello, the Virginia home where Thomas Jefferson's dream of the New World as an Arcadian agricultural idyll fell apart during the "Tambora period".

Also making an appearance is John Barrow. This scheming second secretary to the British Admiralty successfully petitioned his employers to resume the quest for a North West Passage on the basis of whaler William Scoresby's reports of ice-free waters off northern Canada in 1817, with support from naturalist Joseph Banks at the Royal Society. With Napoleon defeated, Navy men needed to be kept busy. Many, Rear Admiral John Franklin being the best known, were sent to their deaths in the following decades: Tambora's far-flung climatic effects having waned, the ice returned with a vengeance and destroyed them.

This book is much more than brilliant popular science. Drawing together a world of data relating to this epochchanging eruption, Wood has made a major contribution to volcanology, climatology and cultural history, driven by personal passion and conviction.

Ted Nield edits the magazine Geoscientist for the Geological Society of London. His book Underlands (Granta Books) is due out in May. e-mail:ted.nield@geolsoc.org.uk

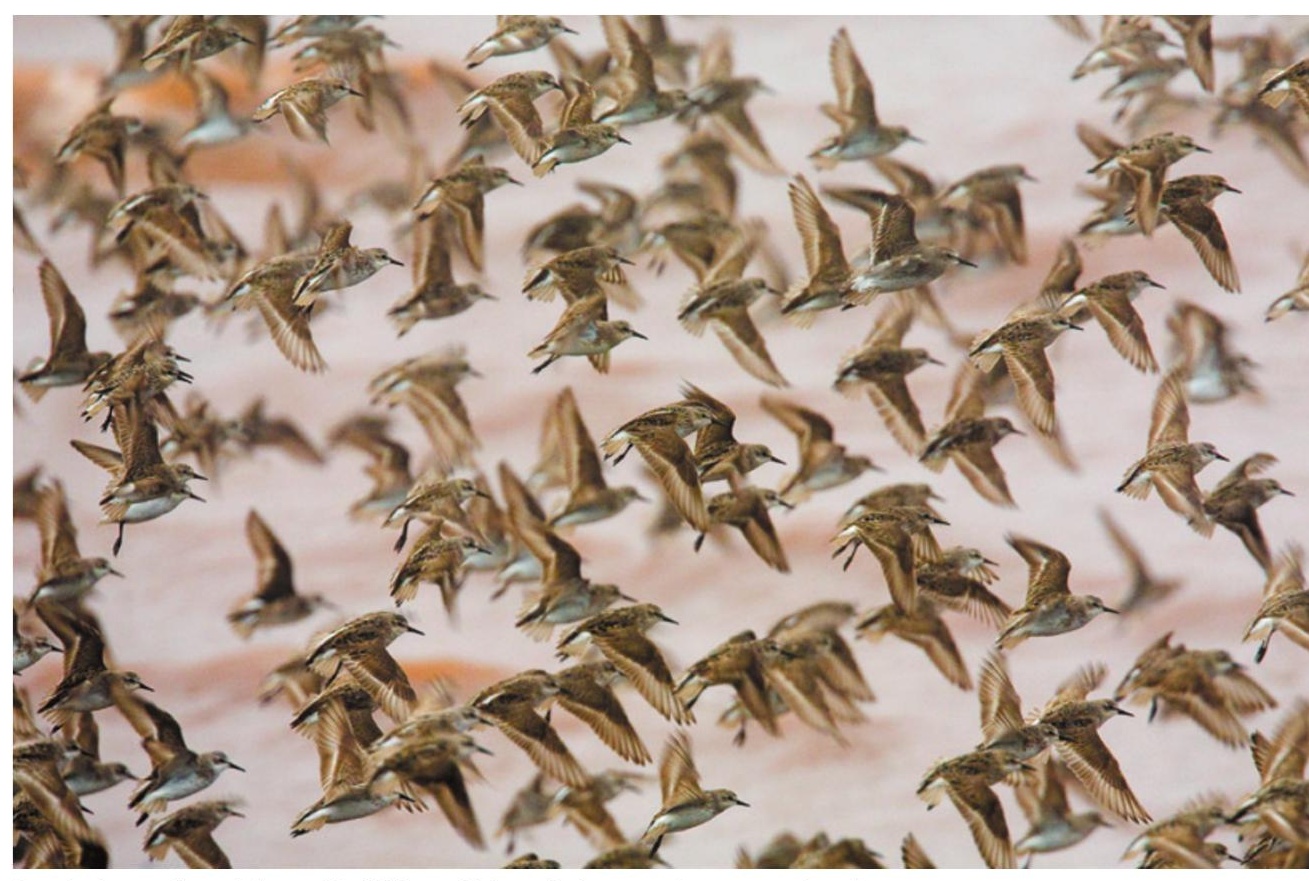

Semipalmated sandpipers (Calidris pusilla) on their annual autumn migration.

ANIMAL BEHAVIOUR

Nomads of necessity

\section{Joel Greenberg casts an ornithologist's eye on a wide-ranging reading of animal migration.}

A nimal migration is a wondrous thing. Driven by seasonal changes in daylight and other factors, an incredible array of organisms fly, creep or run through urban and other habitat-restricted areas on their way to or from richer spots for wintering, feeding or breeding. When you watch the movement of migrants (and I know birds best), you see the beauty of the individuals, and are privy to the performance of ancient commands dictated by genetic coding. It is often a species' most vulnerable moment. Human-driven and other shifts can occur too quickly for an individual to adjust: a bird that has flown all night looks down at the landscape that emerges at dawn, and seeks an accommodating wood that may or may not still be standing.

In The Homing Instinct, biologist Bernd Heinrich explores the concept of 'home' - how organisms in a wide range of taxa, including insects, arachnids, amphibians, fish, birds and mammals, arrive at their destinations, construct or alter home territories, and live in them. He discusses the placement of nests according to geographic and site-specific factors; nest structure and hygiene; parasitism and feeding behaviour. In the telling, he relies on the latest scientific advances as well as his own field observations.

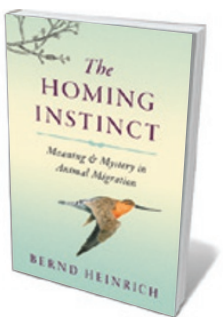

The Homing Instinct: Meaning and Mystery in Animal Migration BERND HEINRICH Houghton Mifflin Harcourt: 2014 endurance of the bar-tailed godwit (Limosa lapponica).

This long-billed, long-legged shorebird was known to nest in the Arctic and winter in Australia and New Zealand. In a 2009 study, transmitters were placed on 23 of the birds to track their flight paths. They revealed that the species can fly from Alaska to New Zealand in less than nine days without stopping, riding wind currents and expending half their body weight (R. E. Gill Jr et al. Proc. R. Soc. B 276, 447-457; 2009). (On the way north, the birds do stop to feed.)

Heinrich discusses at length how 